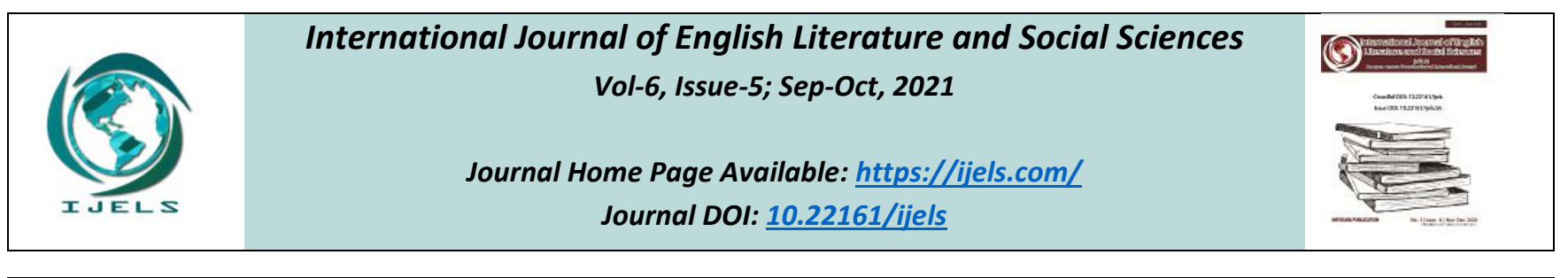

Peer-Reviewed Journal

\title{
History, Gender and Class in Adam Bede and Anna Karenina
}

\author{
Rameez Ahmad Bhat
}

Research Scholar, Dept of English, Aligarh Muslim University, India

Received: 15 Sep 2021; Received in revised form: 19 Oct 2021; Accepted: 25 Oct 2021; Available online: 31 Oct 2021

(C)2021 The Author(s). Published by Infogain Publication. This is an open access article under the CC BY license

(https://creativecommons.org/licenses/by/4.0/).

\begin{abstract}
This paper explores some of the significant issues touched upon in two novels regarded as the seminal works in the tradition of the realistic mode: Adam Bede and Anna Karenina. The issues it deals with are history, gender and class. It starts by the claim that literature, here in the case of the novel, reflects, represents or imitates the reality or the world of which it is part and explores the way the three aspects have been incorporated in these novels. The idea here is to account for the fact that marginalisation of people in the Western Canon was based on gender, class, and colour. Countering the top-down vertical approach to literature it takes the bottom-up or subaltern perspective to explain the condition of women and working or peasant class in these novels.
\end{abstract}

Keywords-Class, gender, marginalisation, realistic tradition, representation, subaltern approach.

Until quite recently, writing of history or historiography had been not only the vocation of only a small elite, class, gender, nation, sex or race but the themes it represented were no more than what some historians say autobiographies of these elites. Underlying this project was the idea to construct a binary so as not merely to define themselves from the other but construct the "other", and thereby, according to Eagleton (2010), a hierarchy where the first category is privileged as the "norm "over the second as "the inferior" (p. 287).In western tradition in general and in Anglo-Saxon tradition of literature in particular, right from the theories, for instance, laid down by Plato and Aristotle, regarding the subject matter and characterisation in literature, down to the nineteenthcentury novel writing, the idea of making the epicentre of the main plot characters from the lower ranks of society was unimaginable(Walder, 1995,p. 3;Morris,2003, p. 52). Alternatively, even if they somehow did, however, it was only because in a sense to disparage them, for instance, as "mad doubles of virtuous heroines, midnight witches and monsters"(Morris, 2003, p. 81). Contrastingly, however, the focal point of literature would revolve, as in other discourses, around characters white, male, upper class, European, or heterosexual. Only those defined suitable to fit into the parameters of these discourses were considered for the inclusion as the subject matter in literature, and the rest were put actually to rest as inappropriate or the other. It was, however, the realist movement of the nineteenth century Europe in literature in general and novels such as Anna Karenina and Madame Bovary and several others in particular that moved away from neoclassical decorum and shocked and scandalised this sensibility and morality by breaking these exacting standards(Abrams, 2015).In writing about the role of British novelists, Morris (2003) writes that from Jane Austen to Thomas Hardy, they followed in the steps of the European ones in what she calls the "democratic impulse of realism" moving "away from the world of the higher gentry to the working-class sphere of characters like Tess D'Urbervilles and Jude the Obscure" (p. 79).

Abrams (2015) describes the realistic novel "as the fictional attempt to give the effect of realism, by representing complex characters with mixed motives who are rooted in a social class, operate in a developed social structure, interact with many other characters, and undergo plausible, everyday modes of experience" (p. 224). The representation of and rootedness in a social class is highly 
discernible in the two novels in question. Oxford Learner's Dictionary of Academic English(2014) defines a class as, "one of the groups of people in a society that are thought of as being at the same social or economic level" and "the way that people are divided into different social and economic groups" (p. 89). It follows that in both novels, therefore, class distinction is likely discernible. For instance, it can be perceived that the entire thrust of the novel, Anna Karenina, is the elite or royal society of the time around which the main plot hinges, often called the "novel of manners", and those of non-elite and non-royal classes are only in part hinted at (Abrams, 2015, p. 224). There is, however, no detailed description of the issues regarding peasants and working-class let alone character delineation as is done in the case of the former. The descriptionprovided thoughis of the homes and the like of the latter class in great detail. From the very first chapter of Anna Karenina(2003), we can see, for instance, that the narrative follows a detailed description of the "family and household of Oblonskys" thus:

All was confusion in the Oblonskys' house. The wife had found out that the husband was having an affair with their former French governess, and had announced to the husband that she could not live in the same house with him. This situation had continued for three days now and was painfully felt by the couple themselves, as well as by all the members of the family and household. They felt that there was no sense in their living together and that people who meet accidentally at any inn have more connection with each other than they, the members of the family and household of the Oblonskys. The wife would not leave her rooms, the husband was away for the third day. The children were running all over the house as if lost; the English governess quarrelled with the housekeeper and wrote a note to a friend, asking her to find her a new place; the cook had already left the premises the day before, at dinnertime; the kitchen maid and coachman had given notice. (Tolstoy, p. 1)

Besides, compare it, in contrast, with the kind of description given to a "watchman" mowed down by the train Anna travels in to reconcile the household of Oblonskys:

A watchman, either drunk or too bundled up because of the freezing cold, had not heard a train being shunted and had been run over. Even before Vronsky and Oblonsky came back, the ladies had learned these details from the butler. Oblonsky and Vronsky had both seen the mangled corpse. Oblonsky was obviously suffering. He winced and seemed ready to cry. 'Ah, how terrible! Ah, Anna, if you'd seen it! Ah, how terrible!' he kept saying. Vronsky was silent, and his handsome face was serious but perfectly calm. 'Ah, if you'd seen it, Countess,' said Stepan Arkadyich. 'And his wife is here ... It was terrible to see her ... She threw herself on the body. They say he was the sole provider for a huge family. It's terrible!'(2003, p. 64)

The narration does not follow the trail as to the details of their household any further, and we are led instead into the concerns of a couple of royal families. Besides, out of wedlock affairs of this class are made so prominent so as to build the whole plot around them, and in contrast, only a few lines tend to be devoted to the life of the watchmen and his wife and "a huge family" (2003, p. 64). Why does the narrative not follow this huge family to investigate their life whose only breadwinner has been run over? This is perhaps to foreground the idea that in history, as in literature, the domain of the elite, royal or upper class, no no-royal or lower class characters could be encompassed. In another glaring example of underrepresentation, the muzhiks are not given due credit as the aristocratic ones. Their characterisation, not necessitating any delineation, is only kept to being "two dimensional" (Forster, 1927, p. 52).

However, the elitism both in the writing of history and in literature, as the classical theory of art would have it, can perhaps be argued to be refuted in Adam Bede because the novel incorporated into its main plot characters who are ordinary and belong to the working or peasant class. The leading families around which the entire plot is set also compriseof ordinary common ones without any large estates which the writer explains in the first paragraph of the novel as,"with this drop of ink at the end of my pen, I will show you the roomy workshop of Mr. Jonathan Burge, carpenter and builder, in the village of Hayslope, as it appeared on the eighteenth of June, in the year of our Lord 1799" and we are led into the company of workmen of Adam Bede and Seth's adoption of Methodism and the preaching of what the doctrines of it entailed (1859, p. 1).The inclusion in the main plot of Methodism which had its primary principle "a concern for the underprivileged and the improvement of social conditions", bespeaks the exclusion of the village and its people from the mainstream London because, "under the leadership of Whitefield and then of Wesley, the movement proliferated among those who felt neglected by the Church of England" (Davies, 2019).

The exhaustive portrayal provided of the village of Hayslope, its people, and its surroundings, moreover, can be claimed to be a classic example of the bottom-up approach to history and its characters. The plot follows their everyday concerns, their occupations, church-going 
etc. in detail. Added to this is also the fact of unfolding the characters" physiognomy, demeanour and temperaments. For instance, from his "voice" to his "mixture of Celtic blood" Adam is painted as thus:

Such a voice could only come from a broad chest, and the broad chest belonged to a large-boned, muscular man nearly six feet high, with a back so flat and a head so well poised that when he drew himself up to take a more distant survey of his work, he had the air of a soldier standing at ease. The sleeve rolled up above the elbow showed an arm that was likely to win the prize for feats of strength; yet the long supple hand, with its broad finger-tips, looked ready for works of skill. In his tall stalwartness Adam Bede was a Saxon, and justified his name; but the jet-black hair, made the more noticeable by its contrast with the light paper cap, and the keen glance of the dark eyes that shone from under strongly marked, prominent and mobile eyebrows, indicated a mixture of Celtic blood. The face was large and roughly hewn, and when in repose had no other beauty than such as belongs to an expression of goodhumoured honest intelligence. (Eliot, 1859, p. 2)

Even his pet dog is described in such vivid detail:

Hitherto Gyp had kept his comfortable bed, only lifting up his head and watching Adam more closely as he noticed the other workmen departing. But no sooner did Adam put his ruler in his pocket, and begin to twist his apron round his waist, than Gyp ran forward and looked up in his master's face with patient expectation. If Gyp had had a tail he would doubtless have wagged it, but being destitute of that vehicle for his emotions, he was like many other worthy personages, destined to appear more phlegmatic than nature had made him. (1859, p. 8-9)

The concept of gender plays a crucial role in feminist scholarship. The overall feminist argument emerged in the idea of gender as a category worthy of taken into account seriously and its challenge has primarily been to refute the idea of casting it in the negative. The recent debates surrounding MeToo Movement, however, have shown how gender discrimination has been, even in progressive democratic structures of the world including India as well, pervasively rampant.During the early or first wave of feminism, for instance, George Eliot can be a case in point. In her life, she mounted against her society in order to be with a married man that was unprecedented for the times she lived in. In a somewhat similar fashion Anna of the eponymous novel,Anna Karenina did the same. The fact that both the novels, Anna Karenina and Adam Bede, have been inspired by two real-life incidents happened with two women in two different societies accounts for the entrenched established gender discrimination across borders. Hetty, in the latter, is led to execution for killing her out of wedlock child and, in the former, Anna is pushed to committing suicide (Drabble, 2000, p. 6).

Even though Emma is a member of a royal family and the wife of a well-established man, however, her choice of having an affair out of wedlock with a man she vehemently proclaims she is in love with is looked down upon as a "liaison" (Tolstoy, 2003, p. 127). She, however, takes her own decisions regardless of consequences, singlehandedly fights her way out in this patriarchal world she inhabitsand in the end, fails to achieve what she really wanted to obtain-divorce-but could not because the law, Christian law, did not grant to a "fallen" woman(2003, p. 706).Moreover, her husband did it allow it to happen at all when everything was in his hands, because, for him, the woman of her "magnanimous" nature could not be in a "tormenting situation" just for a divorce which, for Anna, her brother, Stephen Arkadyich, pleads to Alexei Alexandrovich, is all she wants:

She leaves it all to your magnanimity. She begs, she beseeches you for one thing-to bring her out of the impossible situation in which she finds herself. She no longer asks to have the boy. Alexei Alexandrovich, you are a kind man. Put yourself in her situation for a moment. The question of divorce in her situation is for her a question of life and death. (2003, p.724)

It can be seen, moreover, that there is a recurrent enmity or suffering in almost every marriage in Anna Kareninaeither through the "affairs" of the husband, as in Oblonskys, or through a change of behaviour just after marriage, as in Anna and Vronsky and Levin and Kitty. For instance, Anna blames Vronsky for everything she has been going through in her life:

And, being jealous, Anna was indignant with him and sought pretexts for indignation in everything. She blamed him for everything that was difficult in her situation. The painful state of expectation, between heaven and earth, in which she lived in Moscow, Alexei Alexandrovich's slowness and indecision, her seclusion - she ascribed it all to him. If he loved her, he would understand the full difficulty of her situation and would take her out of it. The fact that she was living in Moscow and not in the country was also his fault. He could not live buried in the country, as she wanted to. Society was necessary for him, and he put her into that terrible position, the difficulty of which he did not wish to understand. And it was he again who was to blame for her being for ever separated from her son (2003, p. 740). 
The discord between the two had its roots set so deep that neither talked about what "irritation" they had with one another, as can be seen in this passage:

The irritation that divided them had no external cause, and all attempts to talk about it not only did not remove it but increased it. This was an inner irritation, which for her was based on the diminishing of his love, and for him on his regret at having put himself, for her sake, in a difficult situation, which she, instead of making easier, made still more difficult. Neither of them spoke of the causes of their irritation, but each considered the other in the wrong and tried to prove it at every opportunity. (2003, p. 739)

Also, Kitty and Levin could not find any respite in their marriage even though they had a daughter together but would quarrel often:

Theirquarrels were another disenchantment and enchantment. Levin never imagined that there could be any other relations between himself and his wife than tender, respectful,loving ones, and suddenly, in the very first days, they quarrelled, and she told him he did not love her, loved only himself, wept and waved her hands. (2003, p. 481)

Even the failures of Emma and Kevin, belonging to the same stock, the aristocratic one, speak volumes about the idea prevalent in the novel that thosewho rebel against this elitism and its associated laws would perhaps meet the same fate. At the end of the novel, the question arises: Why does she commit suicide? Perhapsit is not only because she feels a change of behaviour in her lover towards her but also because she rises against thesexist and patriarchal society and its associated norms. Her only goal of life had been to not only like him but to serve him as well for it was the reason she started reading books so that she could be of any help. However, all this was interpreted and taken by him as "hampering his freedom"(2003, p. 643).

The lack of masculinity,much less prized by patriarchy, shown by her husband, Alexi Alexandrovich, by not pulling the reigns, as the patriarchal ideology would have demanded of him, is perhaps the reason for his suffering. Rather than listening towhat Anna demands,nevertheless, what he often does is he reminds her of his status in the society,her "affair" would put at risk. It seems highly likely and less surprising that in such a fraught marriage that Anna would not care to bother about his unhappiness whenever his memory strikes her in Paris with Vronsky, her lover, which the narrator captures thus, "the memory of her husband's unhappiness did not poison her happiness. . Of course it was bad, but it was the only salvation, and it was better not to remember those dreadful details"(2003, p. 463-4).He kept being blind not only to his wife's feelings but his child as well. Justafter he sensed and heard about her feelings for another man, he does not discuss it in detail with her to find a solution and instead "closed, locked and sealed the drawer in which he kept his feelings for his family - that is, his wife and son" (2003, p. 201).He did not, as Anna claims, care about her and their family who for him werenothing more than "ambition" which the narratorclaimsthat she "knew all his ways and they were all disgusting to her. 'Nothing but ambition, nothing but the wish to succeed - that's all there is in his soul,' she thought, 'and lofty considerations, the love of learning, religion, are all just means to success" (2003, p. 207). Whatever feelings she expressed were, to him, nothing more than empty signifiers repeating themselves in an endless chain, the narrator writes:

She said all this gaily, quickly, and with a special brightness in her eyes, but Alexei Alexandrovich now ascribed no significance to this tone. He heard only her words and gave them only that direct meaning which they had. And he answered her simply, though jocularly. There was nothing special in their conversation, but afterwards, Anna could never recall that whole little scene without a tormenting sense of shame. (2003, p. 205)

In their fight for Hetty'shand,Adam and Arthur Donnithornedo not ask her even once what she wants to do for her own life instead they engage in the fight without realising that they undermine her right to choose. When she does, however, she ends up in prison for the crime she did not commit intentionally.From the very beginning of the novel, she appears as a woman who is not allowed to have a say in her own life. Her uncle and aunt, who have been raising her, wanted her to take Adam as her husband, about whom the narrator says, "it was clear that they would have welcomed the match with Adam for a penniless niece" (Eliot, 1859, p. 108). They did not think Adam as below their "rank" but as a person who had everything that "rank" entailed because it was the time:

When there was no rigid demarcation of rank between the farmer and the respectable artisan, and on the home hearth, as well as in the public-house, they might be seen taking their jug of ale together; the farmer having a latent sense of capital, and of weight in parish affairs, which sustained him under his conspicuous inferiority in conversation. (1859, p. 107)

Nevertheless, to Hetty such was not what she thought of about Adam. For her "he was - a poor man with old parents to keep, who would not be able, for a long while to come, to give her even such luxuries as she shared in her uncle's house" (1859, p. 109). If she marries him, however, 
she could not be able to fulfil her dreams as he was not a rich man but a poor carpenter in a small village who could not afford her the "luxuries" she enjoyed in her uncle's house and those she dreamt of such as:

And Hetty's dreams were all of luxuries: to sit in a carpeted parlour, and always wear white stockings; to have some large beautiful ear-rings, such as were all the fashion; to have Nottingham lace round the top of her gown, and something to make her handkerchief smell nice, like Miss Lydia Donnithorne's when she drew it out at church; and not to be obliged to get up early or be scolded by anybody. (1859, p. 109-10)

She could marry him, however, if he is rich. In contrast to Hetty stands the Methodist preacher, Dinah, for her such dreams would be nothing more futile to demand a hand of Adam in marriage. As a Methodist, what for her would matter the most would perhaps be less Hetty's "luxuries" than a simple and ordinary a person with a heart full of pure feelings. He character is unprecedented in that she is a woman preacher, a vocation for men. In her sermon, she is not asked what the doctrines of Methodism were, but rather how and when she, as a woman, first came under its teachings. For at that time in Anglican Church, preaching had been, as of other "vocations", the domain of men (1859, p. 96).

To sum up, then, it can perhaps be said that the two novels, Anna Karenina and Adam Bede, embodied the spirit of their respective ages and societies they are part of in many ways and gave voice to the issues of history, class and gender discussed in this piece.

\section{REFERENCES}

[1] Eagleton, M. (Ed.). (2010). Feminist Literary Theory: A Reader (3rd ed.). Wiley-Blackwell.

[2] Walder, D. (1995). The Genre Approach. In W. Dennis, The Realist Novel. The Open U.

[3] Morris, P. (2003). Realism. Routledge.

[4] ibid. p. 81.

[5] Abrams, M. H. (2015). A Glossary of Literary Terms. Cengage Learning.

[6] Morris, 2003, p. 79.

[7] Abrams, p. 224.

[8] Oxford. (2014). Oxford Learner's Dictionary of Academic English. OUP.

[9] Abrams, p. 224.

[10] Tolstoy, L. (2003). Anna Karenina. (R. Pevear, \& L. Volokhonsky, Trans.) Penguin Classics.

[11] ibid., p. 64.

[12] ibid.

[13] Forster, E. M. (1927). Aspects of the Novel. Penguin Classics.
[14] Eliot, G. (1859). Adam Bede. Vintage Classics.

[15] Davies, R. E. (2019). Methodism. Retrieved from Encyclopaedia Britannica: https://www.britannica.com/topic/Methodism

[16] Eliot, p. 2.

[17] ibid., p. 8-9.

[18] Drabble, M. (Ed.). (2000). The Oxford Companion to English Literature. OUP.

[19] Tolstoy, p. 127

[20] ibid., p. 706.

[21] p. 724.

[22] p. 740.

[23] p. 739.

[24] p. 481.

[25] p. 643.

[26] p. 463-64

[27] p. 201.

[28] p. 207.

[29] p. 205.

[30] Eliot, p. 108.

[31] ibid., p. 107.

[32] p. 109.

[33] p. 109-10.

[34] p. 96. 